\title{
RAWLS'S NORMATIVE CONCEPTION OF THE PERSON: \\ A Kantian reinterpretation
}

Nythamar de Oliveira

RESUMO - Trata-se de mostrar em que sentido a concepção normativa de pessoa em John Rawls pressupõe uma transformação semântica da concepção kantiana de subjetividade transcendental, em particular do seu ideal de personalidade (Persönlichkeit). Uma reinterpretação kantiana da concepção normativa de pessoa logra explicar o dispositivo procedimental do equilíbrio reflexivo para responder a críticas comunitaristas em defesa do individualismo inerente ao liberalismo político, concebido não mais como uma doutrina abrangente da auto-identidade mas como um construtivismo, num modelo coerentista de justificativa epistêmico-moral.

PALAVRAS-CHAVE - Construtivismo. Equilíbrio reflexivo. Liberalismo político. Personalidade.
ABSTRACT - The article seeks to show in which sense Rawls's normative conception of the person does presuppose a semantic transformation of the Kantian conception of transcendental subjectivity, particularly of his ideal of personhood (Persönlichkeit). A Kantian reinterpretation of the normative conception of the person succeeds in accounting for the procedural device of reflective equilibrium so as to address communitarian criticisms in defense of the individualism inherent in political liberalism, conceived no longer as a comprehensive doctrine of selfidentity but as a constructivism, within a coherentist model of moral epistemology.

KEY WORDS - Constructivism. Personhood. Political liberalism. Reflective equilibrium.

1. The publication of John Rawls's A Theory of Justice in 1971 was not only a landmark in ethics and political philosophy, but has also proved to be a decisive contribution to research in the philosophy of law, political sociology, and social psychology, and, to a less obvious degree, in ongoing discussions in metaphysics, moral epistemology, philosophy of religion, and philosophy of mind. As it has become quite known in the debate opposing universalist and communitarian models of moral reasoning in political philosophy, Rawls conceives of an original position as an attempt to model the considerations that determine the principles of justice for a well-ordered society, in which public criteria for judging the feasible,

An original version of this paper was read at the Brazilian Association of Philosophy (Anpof) meeting in Salvador and at the Australasian Association of Philosophy, New Zealand Division Meeting, in Wellington. I am grateful to CNPq and Capes for their financial support. I am indebted to Maurice Goldsmith, Ruth Irwin, Ramon Das, Susi Killmister, Jeremy St. John, and David Hunter for their comments.

Pontifícia Universidade Católica do Rio Grande do Sul - PUCRS/CNPq.

\begin{tabular}{l|l|l|l|l|r|} 
VERITAS & Porto Alegre & v. 52 & n. 1 & Março 2007 & p. 171-183
\end{tabular}


basic structure of society would be publicly recognized and accepted by all. Hence the procedural device of rules or public criteria which parties in the original position would endorse prudentially is to be constructed from behind a veil of ignorance, so that the parties know nothing specific about the particular persons they are supposed to represent. One of the most original, polemical features of Rawls's conception of justice as fairness was undoubtedly his "Kantian interpretation" of the self, at the heart of his theory, co-related to the notions of autonomy, proceduralism, and constructivism. According to Rawls,

Kant held, I believe, that a person is acting autonomously when the principles of [her] action are chosen by [her] as the most adequate possible expression of [her] nature as a free and equal being (...) By acting from these principles [i.e. chosen by the parties in the original position, behind a veil of ignorance] persons express their nature as free and equal rational beings subject to the general conditions of human life (TJ $\S 40 \mathrm{p}$. 222). ${ }^{1}$

And he goes on to assert that the "principles of justice are also categorical imperatives in Kant's sense."(TJ§ 40) What was then controversial about Rawls's "procedural interpretation of Kant's conception of autonomy" so remains in that even though he was assuming that the person's choice as a noumenal self is to be taken in collective terms, Rawls's theory still seems to fall within the so-called individualist tradition, which together with liberalism and universalism, has come under attack by communitarianism. I agree with Philip Pettit in that Rawls's individualism is rather moral than of the metaphysical type, insofar as "whatever their metaphysical status, it is only individual agents who matter in the design of sociopolitical institutions and it is only the interests of individuals that we ought to take into account in devising such arrangements." ${ }^{2}$ My guiding thesis here is that Rawls's normative conception of the person is perhaps the best way to account for his ingenious strategy of resorting to a reflective equilibrium, conceived as a procedural device between a nonideal theory of human nature (where we find "ourselves" and our considered judgments or common sense intuitions of right and good) and an ideal theory, in which a public conception of justice refers to free and equal persons with two moral powers (sense of justice and conception of the good). The reflective equilibrium belongs thus together with the original position and the well-ordered society, so as to carry out the thought-experiment of an ideal theory of justice which ultimately meets nonideal needs and capacities. Rawls himself thought that the original 1971 version of the account of goodness in chapter VII of TJ "left it ambiguous whether something's being a primary good depends solely on the natural facts of human psychology or whether it also depends on a moral conception of the person that embodies a certain ideal."(TJ p. xiii) And

\footnotetext{
I am taking the liberty to use inclusive language whenever it seems suitable. I am using the following abbreviations: John Rawls, A Theory of Justice, Revised edition, Oxford University Press, 1999 (TJ); Political Liberalism, New York: Columbia University Press, 1993 (PL).

2 Chandran Kukathas \& Philip Pettit, A Theory of Justice and its Critics, Stanford University Press, 1990, p. 11.
} 
he went on to add that "persons are to be viewed as having two moral powers and as having higher-order interests [i.e., purely formal interests in the content and fulfillment of other interests, just like second-order desires are desires about desires] in developing and exercising those powers."

In his Political Liberalism (1993) Rawls explains that, besides the first two higher-order interests in developing and exercising the two moral powers (i.e., a capacity for a sense of justice and a capacity for a conception of the good), a third higher-order interest is brought in to describe the parties' deliberations in their modeling of citizens' rational autonomy, namely, "to protect and advance some determinate (but unspecified) conceptions of the good over a complete life."(PL p. 74) The normative conception of the person, according to Rawls, "begins from our everyday conception of persons as the basic units of thought, deliberation, and responsibility, and [is then] adapted to a political conception of justice and not a comprehensive doctrine" (PL p. 18 n. 20). Such a political conception of the person must be thus distinguished from an account of human nature (in natural and empirical sciences, as well as in social theory), precisely because it turns out to be most suitable for the basis of democratic citizenship.

2. Now, it is well known that Michael Sandel's critique of the liberal conception of the self played an important role in Rawls's later attempts at recasting his theory of justice as a noncomprehensive, political liberalism. In Liberalism and the Limits of Justice (1982, p. 21 ff), Sandel proposed a radically situated self to oppose Rawls's radically disembodied subject, so as to question that the self, within any defensible political theory, be conceived as prior to its ends, which in Rawls's deontological model, were inevitably a posteriori (e.g., when Rawls says that "the self is prior to the ends which are affirmed by it", TJ p. 491). In order to avoid an antinomy between "a radically situated subject" and "a radically disembodied subject," Sandel undermines the supposedly neutral procedure inherent in Kantian-inspired contractualism and liberalism, as social, cultural, ethnical components of self-identity betray any claims for self-determination, insofar as these ends were not ultimately chosen by isolated, disinterested individuals, but were unveiled by the self's pre-given insertion within a determinate social context, where it emerges as an "embedded self," as opposed to any idealized "unencumbered self." Hence the unattainability of "self-originating sources of valid claims" and their supposedly unconstrained ends (p. 177). The sovereign subject and all the emancipatory claims of modern, post-Enlightenment conceptions of the self seemed doomed to oblivion after Sandel's deconstruction of political mishandlings of Kantian, transcendental subjectivity. However pertinent, Sandel's and the communitarian critique overall has failed not only to take into account previous similar attacks on liberalism (especially Hegel's criticisms of Kant) but, above all, it has missed what is ultimately at stake in this discussion, namely, that ethical, political normativity presupposes a certain conception of reflexivity and a correlative concept of person qua individual self, agent, and citizen, or, in Kantian terms, a form of being whose universalizibility is inseparable from its humanity as an end 
in itself and from its membership in a realm of self-legislators. Moreover, it seems implausible, to my mind, to assume that Rawls simply abandoned the Kantian interpretation of TJ and embraced some soft version of communitarianism in PL.

To begin with, Rawls's assumption that the basic structure of society is the primary subject of a theory of justice as fairness just attests to his post-Hegelian reading of Kant's political theory. In his Lectures on the History of Moral Philosophy, Rawls recalls that for Hegel "any kind of institutional embodiment of the concept of free will is what right is," so that "a system of right is to be justified in virtue of its making actual the concept of a free will that has itself as its object." Rawls correctly remarks that Hegel follows Kant when he approaches the moral law as a law of freedom, insofar as our capacity to act from that law can be said to be the basis of our dignity and to make us members of the realm of ends. To quote Rawls,

By having personality, Hegel says, I am aware of myself as this person [Rechtphilosophie § 35]. Of course, I am also moved by impulses and desires, and limited in my circumstances; yet I am, as a person, simply self-relation, and therefore I know myself as having a will that is indeterminate and free. For I can suppose myself without the particular desires and impulses that move me, and I can imagine myself in other circumstances. $^{3}$

Rawls's contention is that the basic rights of personality do not depend on what our particular desires and needs are. It is, therefore, misleading to characterize such a normative conception of liberalism as though its intrinsic individualism paid no heed to communitarian features or its universalism did not take into account particularist demands on the part of its agents and citizens. The primacy accorded to the individual here is not, after all, genetic, sociological or historical but only ideally normative, in strictly political terms and for the sake of a methodological argument, such as that of a reflective equilibrium to account for the correlation between an original position and a well-ordered society. According to Rawls, this was precisely the role assigned by Hegel to negativity in a dialectic of recognition, say, between the system of rights and the two injunctions "to be a person and to respect the rights of others as persons" and not "to infringe on personality and what it entails." Hegel simply presupposes the Kantian contrast between the concept of a free will (freie Wilkür), the will (Wille) itself, and persons as having a free will, so as to establish the inviolability of persons and their autonomy vis à vis the indeterminacy of human actions and the external constraints of juridification, as the positivation of rights may as well turn out to be rather negative. Therefore, just as the selves play the role of persona in the original position, the focus on the basic structure of society as the main subject of such a theory refers us back to Hegel as much as it relies upon Rawls's "Kantian interpretation" in TJ § 40. Furthermore, sociological, psychological, linguistic, and every other ontologi-

J. Rawls, Lectures on the History of Moral Philosophy, ed. Barbara Herman, Harvard University Press, 2000, p. 240. 
cally conditioned features of the human condition are precisely what constitute and are constituted within a normative conception of the person, insofar as individual selves are intersubjectively constituted as persons, just as they model society and at the same time that society models persons. Rawls's "Kantian interpretation" aimed in effect at overcoming historicist, shallow readings of Kant and other Enlightenment thinkers, who were certainly conditioned by a given cultural milieu, but whose insights and seminal contributions to moral philosophy must be continually reexamined beyond textual exegesis and the so-called "author's intention." Thus, Rawls's "Kantian interpretation" offered in A Theory of Justice (§ 40) can be ultimately reconciled with his later writings (esp. Political Liberalism) as long as his conception of political constructivism is regarded as evolving out of his self-critical recasting of the main arguments for a theory of justice, in agreement with his own critique of Kantian moral philosophy. Whatever may be taken for Rawls's "Kantian interpretation" should not, as Pogge pointed out, be confused with a Rawlsian interpretation of Kant or a Kantian interpretation of Rawls. ${ }^{4}$ My contention here is that Rawls's normative conception of the person is what best explains why his original critique of intuitionism, utilitarianism, and perfectionism in moral reasoning had to give way to a more explicit account of democratic egalitarianism, public reason, and political stability in his later writings on constructivism. That might help us also account for Rawls's apparently unqualified resort to rational choice theories in the first work and subsequent elaboration on deliberative rationality and reasonableness.

3. On the other hand, as Christine Korsgaard has argued, Rawls's "deontology with a Humean face" - to use Sandel's ironic epithet - helps us better understand the role of reflexivity in procedural normativity as an investigation into how we should conceive of ourselves as persons. ${ }^{5}$ Rawls's contention that the normative conception of the person should also address the problem of intergenerational justice means, above all, that whatever makes a person the same individual as time goes by, besides the Humean bundle theory of the self and beyond substantialist views of continued personhood, points to a priority of the self over its ends as it cannot be reduced to passive, accumulated aims, attributes, and purposes thrown up by experience. In Korsgaard's felicitous formula, the self is "not simply a product of the vagaries of circumstance, but always, irreducibly, an active, willing agent, distinguishable from my surroundings, and capable of choice" (p. 19). The Kantian procedural view of freedom, from the standpoint of a non-naturalist, anti-realist challenge to rationalist determinism, turns out to defy many contemporary, taken-for-granted beliefs such as the identification between moral realism and intuitionism. On Rawls's interpretation, Kantian constructivism should be placed, within the contemporary spectrum of metaethics, as a cognitivist model,

Thomas W. Pogge, Rawls, München: C.H. Beck, 1994, p. 189-198.

Christine Korsgaard, "Personal Identity and the Unity of Agency," in Creating the Kingdom of Ends, Harvard U.P., 1996; cf. also her The Sources of Normativity, Harvard U.P., 1996. 
irreducible to any version of Platonism, yet to be spotted somewhere between strict realists and noncognitivists, including utilitarian and prescriptivist versions rejected by Rawls. In effect, Rawls's conception of reflective equilibrium corroborates the interdependence of metaethics and normative ethics, inherent in political philosophy's articulation of practical ethics and social practices, say, as applied to problems of human rights, bioethics, and public policies, within the procedural framework of constitutionalism. A normative conception of the person (e.g. when dealing with the question of human dignity) seems to defy the very substantiveprocedural opposition that misleadingly equates the application of human rights (Menschenrechte), such as the ones formulated in the Universal Declaration of Human Rights (1948) and the Universal Declaration on Bioethics and Human Rights (2005), with the concrete claims of basic constitutional rights (Grundrechte) without attending to cultural, value-laden commitments. One interesting example is the recurrent use of the word "individual" in UN documents and declarations, which seem to betray a liberal, individualist self-understanding of persons, as opposed to communitarian views of tribes and indigenous peoples who rightly refuse the cultural imperialism of dominant worldviews. Yet the resort to individuals, in these cases, seems inevitable for any discourse claiming to protect the human dignity of every single person - i.e., in order to guarantee a reasonable pluralism, cultural diversity, and the ultimate coexistence of conflicting, incompatible worldviews. On Rawls's strategic view of reflective equilibrium, human rights must otherwise refer to peoples rather than to persons or individuals - as cosmopolitans do - precisely because of the specifically political thrust of an overlapping consensus, taken on global scale, insofar as they are to avoid ethnocentrism. ${ }^{6}$

4. Even though I won't be able to tackle this issue here, a normative conception of the person must take into account metaphysical problems of personal identity and theories of the self. As Denis Robinson put it so well,

Persons are supervenient entities. Facts about persons and their persistence are not primitive or independent, but supervene (albeit not wholly determinately) on facts which concern their physical and psychological constituents and properties (but which are not essentially facts about persons).

A normative conception of the person must thus strike a balance somewhere between animalism and humanism, between naturalized and essentialistic views of personhood, so as to avoid various forms of reductionism. "Normative," in this context, refers therefore to whatever must be idealized in a theory of persons (say, as opposed to descriptive features) and, on the other hand, refers also to an important, substantive aspect of ethical theory which cannot be reduced to second-

Cf. J. Rawls, The Law of Peoples, Harvard University Press, 1999

Denis Robinson, "Failing to Agree or Failing to Disagree: Personal Identity Quasi-Relativism," The Monist 87/4 (2004), p. 513 
order discourses such as metaethics but seems rather to confirm some inevitable form of psychological reductionism, as Rawls found in Hume's own epistemologized version of moral psychology. Now, a person (Latin, persona) is usually identified with any living human being, and it has become acceptable nowadays to speak of nonhuman persons such as gods, divine beings, and certain animals (e.g. whales, apes, dolphins) as well as of humans which are not persons (such as in juridical instances of minors and the like). Grosso modo, persons have been assigned the capacity for self-identity, self-consciousness, self-esteem, self-respect, and establishing the realization of ends through the subordination of means (reasoning, personal plan of life, project, finality or purpose in life, autonomy). A moral, rational being is said, therefore, to be accountable for her own acts. Even though Ancient and Medieval conceptions of the person already anticipated some of these features, such as cognition, agreeableness, and volition, they remained within an essentialist or substantialist framework of ontology, epitomized by the JudaeoChristian concept of the human person as the imago dei (God's image and likeness). It was indeed only with the advent of Modernity that the self, subjectivity, and consciousness were explicitly thought in reflective, individual terms, as the Cartesian cogito paved the way for its critical opposing conceptions, such as John Locke's definition of self-identity: "a thinking intelligent being, that has reason and reflection, and can consider itself as itself, the same thinking thing in different times and places; which it does only by that consciousness, which is inseparable from thinking, and as it seems to be essential to it." ${ }^{8}$ As Rawls, Nagel, Korsgaard, and others have shown, Locke's and Hume's empiricist accounts of the self contributed to Kant's own conception of the transcendental self between a rationalist "mental identity" and an account of "personal identity," avoiding both the contention that memory does not make someone the same individual through time and misleading relations, say, of two distinct things in self-identity. Hence Patricia Kitcher prefers to use "mental unity" to describe the Kantian account of personal identity, for instance, when Kant writes that "I exist as an intelligence which is conscious solely of its power of combination." (KrV B 159) That simply means that the thinking self is not, as Kitcher put it so well, "a contentually interconnected system of states, but that which connects cognitive states." ${ }^{10}$ Although the self - just like consciousness or apperception - cannot be reduced to anything like the power or source of spontaneity itself or to its acts of spontaneity, it is said to be the agent that performs these acts, even if they turn out to be unconscious or, as Daniel Dennett suggests, "subpersonal processes," differentiated from acts performed by persons. ${ }^{11}$ Kitcher remarks that Kant has inherited Locke's forensic conception of the person insofar as the term is used "in the assignment of moral

\footnotetext{
J. Locke, Essay on Human Understanding, 1689, Book 2, Chapter 27, Section 9.

$\mathrm{I}$ am using the following abbreviations of Kant's works: $\mathrm{KrV}=$ Critique of Pure Reason; GMS = Groundwork of the Metaphysics of Morals; MdS = Metaphysics of Morals.

10 Patricia Kitcher, Kant's transcendental psychology, Oxford UP, 1993, p. 122.

1 Daniel Dennett, Content and Consciousness, 93 ff. apud. Kitcher, ibid.
} 
and legal praise and blame."(p. 125) Korsgaard recalls the five chapters devoted to Hume's psychologized morality in Rawls's Lectures, as well as the former's views on reflective endorsement and rational deliberation, to point out that the Humean "bundle of perceptions" reissues the theory of ideas just to remain faithful to the sense data and primary level of impressions that constitutes the very "nature of man" at stake in the Treatise. Hence Locke's contradistinction of "man" and "person" is very instructive when one proceeds to see how Kant recasts Hume's fork by proposing a dual view of human nature within a sociable realm of ends. According to Rawls, "when fully articulated, any conception of justice expresses a conception of the person, of the relations between persons, and of the general structure and ends of social cooperation". ${ }^{12}$ As I argue for the Rawlsian correlation between normative model-conceptions of person and society, these must cohere with a free-standing view which does not depend on any particular theory of truth. Hence Rawls's constructivism assumes, in opposition to moral realism and intuitionism, that moral propositions are to be assessed in the context of a broader set of related propositions that we hold to be true, morally right or reasonable. On Rawls's reading of Kant's transcendental philosophy, we must avoid his dualisms in order to escape comprehensive doctrines, such as philosophical anthropology and other metaphysical accounts of human nature. Therefore, Rawls's semantic transformation of traditional theories of the self results in a normative concept of person that claims to be essentially political and nonmetaphysical, insofar as it does not resort to a theory of truth or to an epistemological model of justification to be anchored in reality, and avoids every account for the ground of beings (general metaphysics or ontology). Hence Rawls's coherentism (esp. in the conception of reflective equilibrium) seeks to distinguish itself from the Kantian ideal of personality (Persönlichkeit), just as it refuses to be reduced to naturalist accounts inherent in the empirical sciences. ${ }^{13}$ Rawls recognizes that the concept of persona has been historically linked to that of society, where citizens play social roles as they assume rights and duties in their community relationships, society understood as a fair system of cooperation among free, equal persons (CP p. 396). In effect, the entire development of Rawls's theory of justice as fairness presupposes this interplay of normativity between person and society, through the three viewpoints to be adopted (by the parties in the original position, citizens in a wellordered society, and by "ourselves," all of us "who are faced with the task of settling questions of justice," i.e., concrete, flesh-and-blood humans who share values and beliefs within a given culture, including our more or less intuitive conceptions of good and sense of justice). The reflective equilibrium mediates thus between ideal and nonideal standpoints, and carries through the procedural repre-

2 John Rawls, "A Kantian Conception of Equality" (1975), in Collected Papers, ed. Samuel Freeman, Harvard University Press, 2001, p. 254; hereafter CP.

13 Cf. J. Rawls, "Justice as Fairness: Political not Metaphysical" (1985), in Collected Papers, p. 397 n. 15. 
sentations of the other devices (original position and well-ordered society) - without reducing personhood to social roles and the like. ${ }^{14}$

5. Kant's ideal of personality is not only central to Rawls's "Kantian interpretation" but also translates the very dualisms to be overcome, most notably that of the conjunction of the homo phaenomenon with the homo noumenon. It is therefore a question of perspectivism whether one takes the standpoint of theoretical or practical reason when dealing with human agency in nature, in accordance with Kant's own distinction between negative and positive freedom. For Kant conceives of duties, not only insofar as they are ethical duties, but also as their legislation can be taken outside the scope of ethics, in his doctrine of right (Rechtslehre) so as to comply with the external obligation of the law - one can clearly see how Rawls's early interest in Wittgenstein's rule-following thought-experiments would be combined with Kant's proceduralism and rational-choice theories of games. ${ }^{15}$ In effect, the very conception of Verbindlichkeit (obligation) is what helps us bring together the moral internalism and the legal externalism as distinctive, albeit complementary aspects of the Kantian view of human persons as rational, reasonable beings whose "free choice" (freie Willkür) ought to be self-determined by pure reason alone in order to be said to be actually good, or to qualify the only thing that can be morally good, the will itself (Wille). As the Groundwork (Grundlegung zur Metaphysik der Sitten) allows for the contrast between heteronomous and autonomous approaches to the classical view of human nature, Kant's refusal of theological, teleological, and perfectionist conceptions and the task of setting the supreme principle of morality in autonomy qua freedom point furthermore to an extension of "the conception of humanity, the capacity for setting ends having objective value, to that of personality, the capacity for giving laws which determine all objective value". ${ }^{16}$ As Wolfgang Kersting has shown, just as the Kantian conception of humanity is found in his practical philosophy and not in his anthropology, so the equation of humanity and dignity, already formulated in the Groundwork, is reinforced in the Tugendlehre (Doctrine of Virtue) so as to elucidate the normative function of the oft-misunderstood ideal of personality. In effect, humanity, human dignity, and personality or personhood refer all to one and the same concept: "Menschheit, Würde und Persönlichkeit stehen in einem engen begrifflichen Verweisungszusammenhang und werden von Kant auch häuftig synonym gebraucht." ${ }^{17}$ Hence, in order to arrive at the Kantian definition of an action said to be right "if it can coexist with everyone's freedom in accordance with a universal law, or if on its maxim the freedom of choice of each can coexist with everyone's freedom in accordance with a universal law" (MdS 230), it is not

Cf. "Kantian Constructivism in Moral Theory" (1980), in Collected Papers, p. 320-321.

15 Cf. J. Rawls, "Outline of a Decision Procedure for Ethics" (1951) and "Two Concepts of Rules" (1955), in Collected Papers, p. 1-46.

16 A. Wood, Kant's Ethical Thought, Cambridge University Press, 1999, p. 158.

17 W. Kersting, Wohlgeordnete Freiheit: Immanuel Kants Rechts- und Staatsphilosophie. Berlin: Walter de Gruyter, 1984, p. 203 n. 199. 
so much the question of derivation which is at stake as the presupposed idea of freedom which turns out to be common to both fields, even if one cannot derive one principle from the other. Hence one must read the formulation of the fundamental principle of right as a normative complement to the Grundformel in the GMS, as "right and authorization to coercion," according to Kant, are supposed to "mean one and the same thing" (p. 232). In effect, the articulation of the so-called Grundformel or Universalisierungsformel and the Zweck-an-Sich-Formel in the Grundlegung only comes to its full procedural thrust in the Rechtslehre, precisely because of the call for an effective actualization of the third formula (Reich der Zwecke) through the juridical codification and social, political application of their normativity. The Kantian conception of personality is thus much better elucidated in light of Rawls's critical appropriation, as the latter recasts both Hume's and Hegel's views of human nature, respectively used in a psychological and in a juridical analysis of self-identity that avoids both a naturalized moral epistemology and a juridification of positive rights (Verrechtlichung der Grundrechte). Human persons are thus said to be normatively bound to be reasonable in a way that inevitably refers to their living in a culture whose rationality may vary and indeed conflict, and even produce a clash of civilizations. As far as modus vivendi, comprehensive doctrines, and cultural relativism are concerned, rationality cannot be regarded as being constitutive of an idealized conception of personhood - contrary to most traditional views of philosophical anthropology -, as Rawls reserves the term "reasonable" to characterize the idealized symmetry of free, equal persons' attaining to public reason. Rawls's theory of justice as fairness denies, in effect, any role to be played by truth in the practical realm and confines justice to the political sphere, in particular, to the basic structure of a liberal-democratic society qua unified system of social cooperation among moral persons (i.e., free and equal humans, with a sense of justice and different conceptions of good). Just as Kant shifted away from the non-demonstrable Faktum der Vernunft in the second Critique towards a human practical reason in his later writings (notably MdS and political writings), Rawls also sought to account for the tension between autonomy and heteronomy in the very "unsociable sociability" that characterizes human nature by keeping the two perspectives of an ideal-theoretical proceduralism and of nonideal values (such as shared beliefs within a given culture). Hence the modern problem of articulating ethics and political philosophy through a normative conception of the person lies at the heart of both Kant's and Rawls's critique of metaphysical foundations. For Kant, the place of human persons in nature constitutes the counterpart to the Copernican revolution in theoretical philosophy. Rawls carefully contrasts a plausible interpretation of a Kantian intuitionism in the theoretical use of pure reason (e.g., in the philosophy of mathematics) with the constructivism of his practical philosophy: grosso modo, Rawls refuses moral intuitionism together with any misleading assumption of realism to characterize Kant's cognitivism. However, if Rawls failed to further elaborate on the basic personsociety correlation, it was in part because of his programmatic concern to avoid foundationalist articulations of the problem of human nature with ethics and poli- 
tics, i.e., how the animal rationale is said to be a zoon politikon. Furthermore, Rawls's early remarks on Kohlberg's moral psychology anticipates a reconstructive turn that departs from theories of personality and a subject philosophy of the self towards developmental analyses, coinciding with the so-called "semantic turn" in analytical philosophy. ${ }^{18}$ Still, Rawls seems to be rather evasive when challenged by critics to take into account the "concrete other" and her complex, empirical otherness (e.g., Seyla Benhabib, Nancy Fraser, feminists, and postcolonial crtitics), cutting across the taken-for-granted differentiations of private and public spheres. Hence the perspectival dimension of a post-Rawlsian "transcendental semantics" may successfully account for both identity and difference within a normative conception of the person, without falling prey to the ongoing dialogues de sourds between universalists, communitarians, and cosmopolitans, as these tend to reduce personhood to individuals, peoples, or social communities. It is my contention, thus, that the so-called "clash of civilizations" and the challenges of cultural relativism can be neutralized by a proceduralist, solidary globalization whose normative thrust is highly desirable and realizable, say, through the implementation of human rights within democratizing societies, insofar as they subscribe to such a normative conception of person, to an autonomous, deliberative ethos for local action (ongoing processes of democratization in developing countries and elsewhere) and to a universalizable, egalitarian conception of justice and liberty which avoids the juridification of the person (such as reducing personhood to a positive conception of juridical person that threatens particular expressions of freedom). ${ }^{19}$

6. As early as 1975, Rawls had already anticipated how the notion of a wellordered society required a certain conception of person and society, as he resorted to a Kantian conception of equality:

When fully articulated, any conception of justice expresses a conception of the person, of the relations between persons, and of the general structure and ends of social cooperation. To accept the principles that represent a conception of justice is at the same time to accept an ideal of the person; and in acting from these principles we realize such an ideal. ${ }^{20}$

18 The term is used by both Zeljko Loparic and Robert Hanna to designate the Kantian, transcendental transformation of the Leibnizian-Humean predicament of a priori cognition. On Kant's transcendental perspectivism and transcendental semantics, cf. F. Kaulbach, Studien zur späten Rechtsphilosophie Kants und ihrer transzendentalen Methode, Würzburg, 1982; "Perspektivismus und Rechtsprinzip in Kants Kritik der reinen Vernunft", Allgemeine Zeitschrift für Philosophie 10 (1985): 21-35; Z. Loparic, A semântica transcendental de Kant, Campinas: CLE, 2000; R. Hanna, Kant and the foundations of analytic philosophy, Oxford University Press, 2001.

19 One of the best articulated criticisms of the so-called "juridification of freedom" and the "instrumentalization of human rights" is found in Hans-Georg Flickinger, "Im Namen der Freiheit. Über die Instrumentalisierbarkeit der Menschenrechte", Deutsche Zeitschrift für Philosophie 54/6 (2006): p. 841-852.

20 J. Rawls, "A Kantian Conception of Equality" (1975). In Collected Papers, ed. Samuel Freeman, Harvard University Press, 2001, p. 254. 
Rawls postulates then a well-ordered society as one that "is effectively regulated by a public concept of justice." Secondly, he supposes that the members of a well-ordered society are free and equal moral persons and, thirdly, that a wellordered society is stable relative to its conception of justice. This means, for Rawls, that "social institutions generate an effective supporting sense of justice," allowing for Rawls to conclude that

[... the argument from the original position seems to meet these conditions: [...] the assumption that the parties are free and equal moral persons does have an essential role in this argument; and as regards content and application, these principles express, on their public face as it were, the conception of the person that is realized in a wellordered society. They give priority to the basic liberties, regard individuals as free and responsible masters of their aims and desires, and all are to share equally in the means for the attainment of ends unless the situation of everyone can be improved, taking equal division as the starting point. A society that realized these principles would attain positive freedom, for these principles reflect the features of persons that determined their selection and so express a conception they give to themselves. ${ }^{21}$

Justice as fairness, according to John Rawls, "is a theory of human justice and among its premises are the elementary facts about persons and their place in nature" (TJ p. 257). As opposed to Kant's original conception of pure practical reason, Rawls stresses that fairness qua practical reasonableness is peculiar to human beings - and not to rational beings überhaupt. The introduction of the Humean term "reasonable" in the 1980s, to render the Kantian vernünftig in public, autonomous terms, has indeed consecrated his work as a viable alternative to both rationalist (Hobbesian-inspired) and empiricist (Humean-inspired) theories of justice, as well as to intuitionist and utilitarian models in ethics and political theory. Nevertheless, Rawls's attempt to overcome the dualistic conception of human nature in Kant's constructivism seems to betray here the very strength of a theory of justice that seeks to a balance between egalitarian and libertarian trends in political thought. Precisely because the tension between the social good assigned to a Rousseaunian volonté générale and the individual rights of Lockean liberalism could not be dissolved in a philosophy of history - let alone in a philosophical anthropology -, Rawls recasts Kant's interplay of autonomy and heteronomy in light of an economically determined state of affairs, so that primary goods would meet not only material needs but also the moral demands of his conception of persons: full autonomy is political, not ethical (PL p. 77). The political specificity of his theory succeeds somewhat in bridging the gulf between an ever-growing economic surplus and a decaying moral normativity, and yet it leaves to be desired how the political accounts for the moral (without succumbing to a communitarian turn) and how both the former and the latter are not inherently reduced to an economic effect. The normative thrust of Rawls's theory has, moreover, to deal with two aporias that seem to survive his attacks on dualism, at the heart of his

${ }^{21}$ Ibid., p. 266. 
meticulous conception of personhood, namely: the task of making sense of the difference principle (particularly, the idea of equality) in both substantive and procedural terms within such a normative conception of the person and the inevitable tension between normativity and facticity in the very process of social reproduction and integration of person and society. These two sets of problems were already at stake in Jürgen Habermas's criticisms and brief, fructuous interlocution with Rawls. ${ }^{22}$ And they keep returning to the agenda of any debate opposing universalists and communitarians. As Robert Goodin observed,

Biologically, each 'individual' is made by a 'community' of two others - but to seize upon that as evidence of communities 'making' individuals is akin to the facile attempt to assimilate feminism within orthodox Marxism by pointing out that reproduction is just a form of production like any other. Sociologically and psychologically, individuals acquire their orientation in the world from and in relation to other individuals, who themselves stand in some previously negotiated relation to one another - but even when those pre-existing groups are deliberately organized to shape the next generation (as are teachers or preachers), what they do in pursuit of those objectives can only in the most metaphorical way be assimilated to the activities of a group of farmers 'making' a barn together. ${ }^{23}$

In conclusion, we must be reminded that Rawls did seek to reconcile the liberties of the ancient with the the liberties of the modern, so that his own recasting of a Kantian-inspired normative conception of the person carefully tried to address insightful criticisms raised by communitarians, cosmopolitans, and libertarians alike. However, both universalist and communitarian models of personhood seem to fall short of the concrete challenges posed by a political theory of justice, as they seem to miss the most irreducible mark of those who cannot be legally counted, namely, their bare, naked life - worthless and subhuman, yet so fully human and worthy of recognition as whatever we take for human dignity. Hence a recasting of the reflective equilibrium, within the framework of systemic social exclusion and tremendous global injustice, may still throw light on the twofold challenge of making juridification work for the consolidation of democracy and guaranteeing the inclusion of every "other" who has been excluded by the legal proceduralism of social, economic institutions.

2 Cf. my "Critique of Public Reason Revisited: Kant as Arbiter between Rawls and Habermas," Veritas 45/4 (2000): p. 583-606.

23 Robert E. Goodin, "Communities of Enlightenment," British Journal of Political Science 28 (1988), p. 551. 